Article

\title{
Economic Feasibility of Irrigated Agricultural Land Use Buffers to Reduce Groundwater Nitrate in Rural Drinking Water Sources
}

\author{
Megan M. Mayzelle ${ }^{1}$, Joshua H. Viers ${ }^{2}$, Josué Medellín-Azuara ${ }^{3}$ and Thomas Harter ${ }^{4, *}$ \\ 1 Environmental Horticulture 192, University of California Davis, 1 Shields Avenue, Davis, \\ CA 95616, USA; E-Mail: mmmayzel@ucdavis.edu \\ 2 School of Engineering, University of California Merced, 5200 N. Lake Road, Merced, \\ CA 95340, USA; E-Mail: jviers@ucmerced.edu \\ 3 Civil and Environmental Engineering, 3019 Ghausi Hall, University of California Davis, \\ 1 Shields Avenue, Davis, CA 95616, USA; E-Mail: jmedellin@ucdavis.edu \\ 4 Land Air Water Resources, 125 Veihmeyer Hall, University of California Davis, \\ 1 Shields Avenue, Davis, CA 95616, USA \\ * Author to whom correspondence should be addressed; E-Mail: thharter@ucdavis.edu; \\ Tel.: +1-530-752-2709.
}

Academic Editor: Philip A. Brunner

Received: 1 October 2014 / Accepted: 1 December 2014 / Published: 23 December 2014

\begin{abstract}
Agricultural irrigation leachate is often the largest source for aquifer recharge in semi-arid groundwater basins, but contamination from fertilizers and other agro-chemicals may degrade the quality of groundwater. Affected communities are frequently economically disadvantaged, and water supply alternatives may be too costly. This study aimed to demonstrate that, when addressing these issues, environmental sustainability and market profitability are not incompatible. We investigated the viability of two low impact crops, alfalfa and vineyards, and new recharge basins as an alternative land use in recharge buffer zones around affected communities using an integrated hydrologic, socio-geographic, and economic analysis. In the southern Central Valley, California, study area, alfalfa and vineyards currently constitute $30 \%$ of all buffer zone cropland. Economic analyses of alternative land use scenarios indicate a wide range of revenue outcomes. Sector output gains and potential cost saving through land use conversion and resulting flood control result in gains of at least $\$ 2.3$ billion, as compared to costs of $\$ 0.3$ to $\$ 0.7$ billion for treatment options over a 20 year period. Buffer zones would maintain the economic integrity of the region and concur with prevailing
\end{abstract}


policy options. Thus, managed agricultural recharge buffer zones are a potentially attractive option for communities facing financial constraint and needing to diversify their portfolio of policy and infrastructure approaches to meet drinking water quality objectives.

Keywords: nitrate; groundwater; semi-arid agriculture; disadvantaged communities; land use buffers; economic trade-offs; California

\section{Introduction}

\subsection{Agricultural Water, Nitrogen Use, and Groundwater Nitrate Impacts}

Agriculture accounts for at least $70 \%$ of current freshwater resource use worldwide [1], and $85 \%$ of all consumptive water use (water lost to evapotranspiration [2,3]). In California, nearly 6000 liters per capita per day are used to produce food crops; over $70 \%$ of this is dedicated to irrigation [4]. Excess irrigation has been an important, and often dominant, source of groundwater recharge in semi-arid and arid basins [5,6]. Agriculture is also the principal consumer of nitrogen (N), using about $396 \mathrm{Tg} \cdot \mathrm{N} \cdot \mathrm{yr}^{-1}$ worldwide [7]. Synthetic $\mathrm{N}$ fertilizers account for more than $187 \mathrm{Tg} \cdot \mathrm{yr}^{-1}$ (77\% of all N produced by humans), up from $156 \mathrm{Tg} \cdot \mathrm{yr}^{-1}$ in 1995; the remainder has its origin in manure and leguminous crops [7-9]. Nitrogen is applied to crops in organic form (Norg), as ammonium $\left(\mathrm{NH}_{4}\right)$, or as nitrate $\left(\mathrm{NO}_{3}\right)$. In whatever form it is applied, soil microorganisms ultimately generate $\mathrm{NH}_{4}$ or $\mathrm{NO}_{3}$, which can be synthesized by living organisms, including the target crop [10]. Improved plant nutrition and newly developed crop varieties have resulted in dramatic increases in agricultural production in recent decades, which in turn has enabled improved human nutrition and food security [11].

The misuse and overuse of nitrogenous fertilizers, however, have also resulted in degraded environmental conditions and in threats to drinking water. Nitrate is a highly soluble nutrient [12]. When nitrogen is applied to soil as a fertilizer or in manure, $\mathrm{NO}_{3}$ is often leached to below the root zone without reaching the target crop [1]. Only 50\% of $\mathrm{N}$ applied to agricultural soils is taken up by crops [13]; an additional $\sim 25 \%$ is emitted to the atmosphere, $\sim 2 \%-5 \%$ accumulates in the soil, and the remaining $\sim 20 \%$ is discharged into aquatic systems [9]. While other factors contribute to groundwater nitrate concentrations $[8,14,15]$, the proportion of the total area covered by cropland, pasture, and well-drained soil (which tends to be favored for agricultural production) are often prominent determinants of risk of nitrate leaching to groundwater [16-18], report a positive relationship between the amount of residual soil mineral $\mathrm{N}$ at harvest and the concentration of upper groundwater $\mathrm{NO}_{3}$ concentrations.

Much of leached $\mathrm{NO}_{3}$ accumulates in groundwater [19,20], where high $\mathrm{NO}_{3}$ concentrations cause acidification [21], base-cation depletion [7], and accelerated denitrification, potentially with associated greenhouse gas emissions [22]. When an affected aquifer discharges to surface water, high $\mathrm{NO}_{3}$ concentrations can cause eutrophication leading to hypoxia, toxic algal blooms, shellfish toxification, and fish kills [11,23].

Worldwide, $25 \%$ of the human population resides in arid or semiarid regions and relies on groundwater for daily drinking water consumption [24,25]. These aquifers receive significant recharge from agricultural irrigation, making the quality of agricultural leachate an important determinant of water 
resource quality in these areas. Drinking water with high $\mathrm{NO}_{3}$ concentrations can lead to degraded human health, both directly and indirectly. Excessive $\mathrm{NO}_{3}$ concentrations may reduce nutritional security, increase allergen exposure, and carry greater risk of water-vectored infectious diseases and toxic food intake $[7,11,23]$. Consumption of excessive quantities of $\mathrm{NO}_{3}$ can bring about potentially carcinogenic levels of $\mathrm{N}$-nitroso [26], as well as sufficient quantities of methemoglobin to create an oxygen deficiency [27]. As a result, sustained consumption of high concentrations of $\mathrm{NO}_{3}$ has been linked to cancer [23] and methemoglobinemia in infants [22].

The United States Environmental Protection Agency (US EPA) enforces a $10 \mathrm{mg} \cdot \mathrm{NO}-\mathrm{N} \cdot \mathrm{L}^{-1}$ (or $45 \mathrm{mg} \cdot \mathrm{NO}_{3} \cdot \mathrm{L}^{-1}$ ) as the Maximum Contaminant Level (MCL) for safe drinking water in the United States [28], while the European Union (EU) sets a $50 \mathrm{mg} \cdot \mathrm{NO}_{3} \cdot \mathrm{L}^{-1}$ standard. In the U.S., much of the rural population depends on groundwater as drinking water. More than $20 \%$ of U.S. domestic wells are likely to exceed the MCL for nitrate [19]. In some intensively farmed irrigated areas, MCL exceedance rates in rural domestic wells can be nearly 50\% [16]. In unincorporated communities of the United States that lack a municipal government and state legal status, the responsibility and cost of treating contaminated drinking water or seeking other sources falls to the individual.

\subsection{Groundwater Nitrate Treatment, Non-Treatment, and Prevention Options}

Treatment options for managing groundwater nitrate contamination for drinking water purposes include removing nitrogen from water by way of ion exchange, reverse osmosis, or electrodialysis [29]. These options are typically infeasible for economically disadvantaged communities in highly $\mathrm{N}$-contaminated semi-arid agricultural areas due to the high demand for irrigation water, widespread contamination, and lack of economic resources within the community [30]. Generally considered less costly and resource-intensive are non-treatment options, which include blending, new source development, and land use management [29]. Blending with water of lesser $\mathrm{NO}_{3}$ concentration, and/or new source development, is relatively inexpensive but limited by the availability of nearby additional water [31].

Preventative measures are generally more easily manipulated than treatment options. [7] calculate that feasible increases in crop nitrogen-use efficiency (NUE) would decrease the amount of $\mathrm{NO}_{3}$ produced globally by approximately $15 \mathrm{Tg} \mathrm{yr}^{-1}$; further, improvements in animal manure management could double that number [7]. Improved NUE management practices include applying $\mathrm{N}$ fertilizer quantities better reflective of the plant's needs, as well as limiting excessive water applications and water applications temporally near $\mathrm{N}$ applications. Perennialization and legume intensification has been suggested as means of increasing NUE [1]. Select policy and economic incentives may also drive future gains in improved NUE [1].

In communities for which treatment and non-treatment options prove infeasible due to economic cost or lack of technical and infrastructure capacity, an intuitive response may be to prevent contamination by simply removing agricultural production from land adjacent to the community, effectively creating a fallow buffer zone around the agricultural community which no longer contributes to recharge of the community's wells. However, in arid and semi-arid regions, which are lacking significant natural recharge [32], the implementation of such a fallow zone would merely result in irrigated agricultural land just beyond the fallow zone becoming the principal recharge source for community wells, thus leaving well water $\mathrm{NO}_{3}$ concentrations unchanged unless aquifer denitrification is significant. Furthermore, 
such large-scale implementation of permanent fallow would be disruptive to agricultural production and local job markets.

Thus far the market has not responded to water quality issues, in part because of the tragedy of the commons, and in part because of the inherent temporal lag between pollution creation and solution implementation. Consequently, regulatory land use zoning for appropriate agricultural enterprise is becoming increasingly likely. For example, in (semi-)arid regions, land use buffer zones to protect drinking water sources must be actively managed as a source of low $\mathrm{NO}_{3}$ recharge water [33,34]. Managed groundwater recharge has been used by several districts and cities in California's Central Valley with success [35]. Intentional recharge projects in buffer zones ensure that water with no or low $\mathrm{NO}_{3}$ concentration is reaching community wells, and that $\mathrm{NO}_{3}$-rich water from more distant agricultural fields is being pushed deeper, below the reach of community wells. Typically, intentional recharge projects involve percolation basins, managed wetlands, and aquifer storage and recovery (ASR).

The aim of this study is not toward demonstrating regulation support of market profitability, but to show that environmental sustainability and market profitability are not incompatible. Here, we seek additional, viable alternatives for active recharge management that maintain the economic integrity of the region and concur with prevailing policy options. Specifically, we propose the concept of a protective agricultural buffer zone, and analyze its feasibility with respect to local economics and policy options through an interdisciplinary approach employing economics, social sciences, and water sciences. Using a heavily nitrate polluted irrigated agricultural basin in California's Central Valley as our study area, we first test whether the potential for raising agricultural revenue is correlated with nitrogen fertilizer use and whether that then leads to higher nitrate contamination in affected communities $[8,18,36]$. We then examine specific agricultural land use alternatives, including managed recharge basins, which allow for significant amounts of recharge that would be both economically and environmentally beneficial as potential recharge buffer zone land uses. Finally, policy options complementary to buffer zone establishment are considered, including city management and ownership of buffer zones, land use regulation, and incentives for recharge water provisions.

\section{Experimental Section}

\subsection{Study Area Characterization}

The San Joaquin Valley (SJV) constitutes the southern two-thirds of the Central Valley of California. The semi-arid Mediterranean climate brings limited precipitation during the cool winter months (average January temperature: $8{ }^{\circ} \mathrm{C}$ ), while summers are dry and hot (average July temperature: $26^{\circ} \mathrm{C}$ ). Annual precipitation ranges from less than $200 \mathrm{~mm}$ near the southern end of the valley to just over $400 \mathrm{~mm}$ in the north. Geologically, the valley is a structural trough located between the Coast Range to the west and the Sierra Nevada to the east. It is filled with several thousand meters of marine and continental, highly heterogeneous sediments. Fresh groundwater is found in late Tertiary and Quaternary alluvial fan, alluvial plain, and basin fill sediments that comprise the uppermost $600 \mathrm{~m}$ of the unconsolidated sedimentary valley fill. Surface topography is mostly featureless and flat.

Due to its climate, soil, geomorphology, and relatively abundant supply of both surface water and groundwater, the San Joaquin Valley has risen to national and international prominence in agricultural 
productivity; five of the eight counties in the SJV rank among the top ten agriculturally most productive counties in the U.S., with the market value of agricultural products sold from the SJV totaling $\sim \$ 18.3$ billion [37]. At the same time, over $21 \%$ of SJV residents are living in poverty (compared to $\sim 14 \%$ in 1980 and the California state average of $14.2 \%$ in 2010) and the unemployment rate is $35 \%$ higher than the state average [38]. This makes the SJV is one of the most economically depressed regions in the United States [39]. These circumstances are shared with other key agricultural production areas globally. Of those that are employed, many are temporary and uninsured agricultural laborers; the median agricultural worker wage is $\$ 6,900 \mathrm{yr}^{-1}$, less than $20 \%$ of the median household income of the SJV.

Groundwater from the unconfined to semi-confined alluvial aquifer system serves as the primary drinking water source for nearly $90 \%$ of residents in the SJV [40]. The aquifer utilized by the region's population is a renewable groundwater resource that is principally recharged by surface irrigation, as well as seepage from streams. Particularly on the eastern alluvial fans emanating from the granitic Sierra Nevada and encompassing much of the eastern half of the valley, groundwater resources are highly vulnerable given the relatively high infiltration capacity of mostly medium to coarse textured soils and their underlying sediments, and the absence of extensive fine-grained confining layers within the heterogeneous unconsolidated aquifer system.

Compared to a California-wide rate of $10 \%-15 \%$ [41], groundwater from $24 \%$ of domestic wells in the eastern SJV exceed the MCL for $\mathrm{NO}_{3}-\mathrm{N}$ [42], and more than $40 \%$ of Tulare, Stanislaus, and Merced County wells exceed that MCL [16,43]. In 2007, the exceedances that occurred in the SJV accounted for approximately $74 \%$ of all well MCL exceedances recorded in California [44,45] have indicated a significant relationship between MCL exceedances and proportion of Latino population served among small (less than 200 connections) community water systems (CWS). The poverty rate among US-born Latinos is significantly higher than that of US-born self-identified "whites" (14\% versus $9 \%$ ), and at $27 \%$, foreign-born Latinos experience poverty more than any other demographic group in California [46]. Latinos represent about $39 \%$ of the total population and comprise the majority population in many municipalities in the SJV [39]. Given these demographics, the findings of [45] suggest that households in poverty tend to be more affected by $\mathrm{NO}_{3}$-contaminated water supplies. At the same time, small CWSs are less able to fund $\mathrm{NO}_{3}$ treatment technology or water replacement activities than larger facilities. The United Nations recently expressed concern over such racial disparities in the SJV, and urged the government to eliminate discrimination and implement effective county-wide regulation of drinking water supplies $[47,48]$.

\subsection{Determining Recharge Buffer Zone Area}

Drinking water obtained from wells and its anthropogenic contaminants (including nitrate) originate from land surface recharge or river recharge to groundwater within the so-called source area. Numerous methods exist to delineate the source area associated with specific wells [49]. In unconfined aquifers, absent of detailed hydrogeological data and away from surface water features providing significant recharge (e.g., streams, lakes), an approximate determination of the source area is often made using the principle of conservation of mass: the long-term average discharge, $Q\left(\mathrm{~L}^{3} \cdot \mathrm{T}^{-1}\right)$, from a well is equal to recharge in the source area. If the average recharge rate, $R\left(\mathrm{~L}^{-} \mathrm{T}^{-1}\right)$, is known in the landscape nearby the well, the size of the source area, $A_{\mathrm{s}}\left(\mathrm{L}^{2}\right)$, is equal to the ratio of well discharge rate to recharge rate: 


$$
A_{\mathrm{s}}=Q R^{-1}
$$

If regional groundwater gradients are unknown, the source area is often assumed to be circular with area $A_{\mathrm{s}}$, centered on the well [50]. Here we use a modification of this approach that accounts for the amount of pumping in a community with population $\mathrm{p}$ and a long-term per capita consumption $Q_{\mathrm{p}}$. Then, by the principle of mass balance, the combined source area of all wells within that community is:

$$
A_{\mathrm{s}}=\left(Q_{\mathrm{p}} \cdot p\right) R^{-1}
$$

In California, $Q_{\mathrm{p}}$ averages $265 \mathrm{~m}^{3} \cdot \mathrm{yr}^{-1}$ [51,52]. In the irrigated agricultural regions surrounding most developing communities (DCs) in the $\mathrm{SJV}, R$ is generally about $0.3 \mathrm{~m} \cdot \mathrm{yr}^{-1}$ [35]. The source area size per capita is therefore at least 0.1 ha. Uncertainties about actual groundwater flow direction and about aquifer heterogeneity, and the transient flow dynamics due to seasonal influence of nearby large capacity agricultural irrigation wells lead to areas contributing to recharge of a well to be significantly larger than Equation (2) (e.g., [53,54]. Information regarding groundwater flow, location of community wells, soil characteristics, and current areas of agricultural production may contribute to this determination. Depending on such factors, the buffer may not be circular or even completely surround the community, but rather may balloon off one or multiples sides of the community. Likewise, these factors may affect decisions regarding precisely where recharge basins and specific crops occur within the buffer $[55,56]$. Lacking detailed information, we here assume that the source area of concern forms an annulus around each DC, extending from the boundaries of the DC by some buffer width, $x$, beyond the DC. For a preliminary sensitivity analysis, we initially compute land and crop areas for buffer widths of $500 \mathrm{~m}$, $1000 \mathrm{~m}, 2000 \mathrm{~m}$, and $4000 \mathrm{~m}$. For the final economic analysis, we select the smallest of these alternative buffer zones that provides at least twice the area $A_{\mathrm{s}}$ computed from Equation (2).

\subsection{Beneficial Agricultural Management Practices in Buffer Zones}

With the source area of public water supply wells in DCs likely overlapping largely with irrigated agricultural land uses in the immediate vicinity of the DCs, groundwater protection must focus on achieving clean, potable recharge within that area. Source area protection may consider three broad strategies: abandoning current land use in favor of natural vegetation, constructing groundwater recharge facilities, and altering practices with existing land uses to provide cleaner recharge water.

Abandoning irrigated agriculture and replacing it with natural steppe vegetation would lead to nearly complete loss of recharge due to the semi-arid climate condition and low rainfall rates [32]. Hence, the source area would merely move to up gradient irrigated agricultural areas. Creating direct recharge facilities and converting to agricultural land uses with low risk for groundwater contamination are the most promising land use management options. Land use regulation or voluntary arrangements within buffer zones could offer health and environmental benefits of reduced groundwater nitrate concentrations along with net revenue gains. Land use buffer policies, accompanied by model informed land use planning, could integrate improved management practices, low- or no- input crop types, and/or alternative treatment or prevention options that would serve to decrease $\mathrm{NO}_{3}$ leaching rates within buffer zones while still providing economic benefit [57].

For the SJV, the maximum sustainable annual rate of nitrate leaching loss is on the order of $35 \mathrm{~kg} \cdot \mathrm{N} \cdot \mathrm{ha}^{-1} \cdot \mathrm{yr}^{-1}[30]$. For many perennial and annual crops of the $\mathrm{SJV}$, the estimated $\mathrm{N}$ leaching rate 
is significantly higher than $35 \mathrm{~kg} \cdot \mathrm{N} \cdot \mathrm{ha}^{-1} \cdot \mathrm{yr}^{-1}[58,59]$. Vegetable crops, citrus, and nuts are among those with the potentially largest leaching rates, while alfalfa and vineyards were shown to be among the major crops of the SJV with the least $\mathrm{N}$ leaching potential [59]. This has been confirmed by recent groundwater surveys. For example, [60] investigated shallow groundwater nitrate associated with three land uses: almond orchards, vineyards, and a third land use category that included corn and alfalfa (often grown in rotation), and vegetable crops. In the SJV, corn is often grown as forage near dairies and is subject to manure applications. Vegetables are among those crops with the highest fertilizer application rates [61]. Shallow groundwater nitrate was found to be highest near almond orchards, but was also higher in wells associated with the corn, alfalfa, and vegetable land use group, but lower near vineyards. In a comprehensive survey of domestic wells and wells of rural public water supply systems, Lockhart et al. [16] showed that citrus, fruit and nuts, forage crops (often receiving dairy manure), and proximity to dairies were associated with the highest nitrate concentrations, while vineyards were among the agricultural land uses associated with the least nitrate concentration in domestic wells. Few data exist on $\mathrm{N}$ leaching rates from alfalfa, but observed groundwater concentration in regions with alfalfa as dominant crop (without corn rotation) are typically low in nitrate concentration $[62,63]$. Environmental crop modeling systems including nitrogen hazard indices $[64,65]$, indicate that perennial crops and low or no $\mathrm{N}$-input crops play a prominent role in protecting groundwater quality $[1,66]$.

Among the economically important crops in the SJV, vineyards and alfalfa are thus excellent candidates for establishing a flow of N-poor recharge to groundwater while simultaneously permitting the production of crop with high demand and/or economic value. In addition, recent work by Bachand et al. [67] also demonstrates the potential of alfalfa fields and vineyards to be used for additional groundwater recharge, e.g., using flood waters. Alfalfa and vineyards were selected for the analysis here also because they are in high demand, are suited to the local climate, and require little or no nitrogen fertilizer; as a leguminous $\mathrm{N}$-fixer, alfalfa can be expected to produce relatively low amounts of $\mathrm{N}$ leaching, while allowing for significant groundwater recharge through intentional over-irrigation. The well-drained soils of this region permit over-irrigation for intentional recharge purposes without negatively impacting crop productivity. Of the two, vineyards represent a high-value crop, while alfalfa represents a low-value crop. As a control, we also considered permanently fallowing the buffer zones.

Recharge basins, either constructed or within naturally occurring depressions, are not uncommon in many areas of the SJV [68]. Constructed wetlands and pond systems are alternatives to recharge basins for some communities. While of similar cost and permanency as recharge basins, wetlands and ponds have additional capacity for natural denitrification of contaminated water in addition to being sources of clean groundwater recharge $[69,70]$.

\subsection{Identification of Developing Communities}

Our analysis focuses on the central and southern SJV (Figure 1), referred to as the Tulare Lake Basin (TLB), the largest groundwater sub-basin within the Central Valley aquifer system. The TLB has a population of 2.6 million and encompasses an area of over $20,000 \mathrm{~km}^{2}$, including $15,000 \mathrm{~km}^{2}$ (1.5 million ha) of irrigated agricultural lands. We identified all census-designated places (CDPs) within the TLB [71]. CDPs are population centers delineated for statistical purposes. All CDPs are unincorporated, thereby lacking a municipal government structure and state legal status (Federal 
Register Document E8-2667). Of the 62 CDPs, 16 are classified as disadvantaged communities (DACs), defined as having a median household income (MHI) of greater than $60 \%$ to at most $80 \%$ of the state average. Another 31 are ranked as severely disadvantaged communities (SDACs), indicating a MHI of $60 \%$ or less of the state average [72,73]. Disadvantaged and severely disadvantaged communities are summarily identified here as DCs. The remaining 15 communities are designated here as non-disadvantaged communities (NDACs).

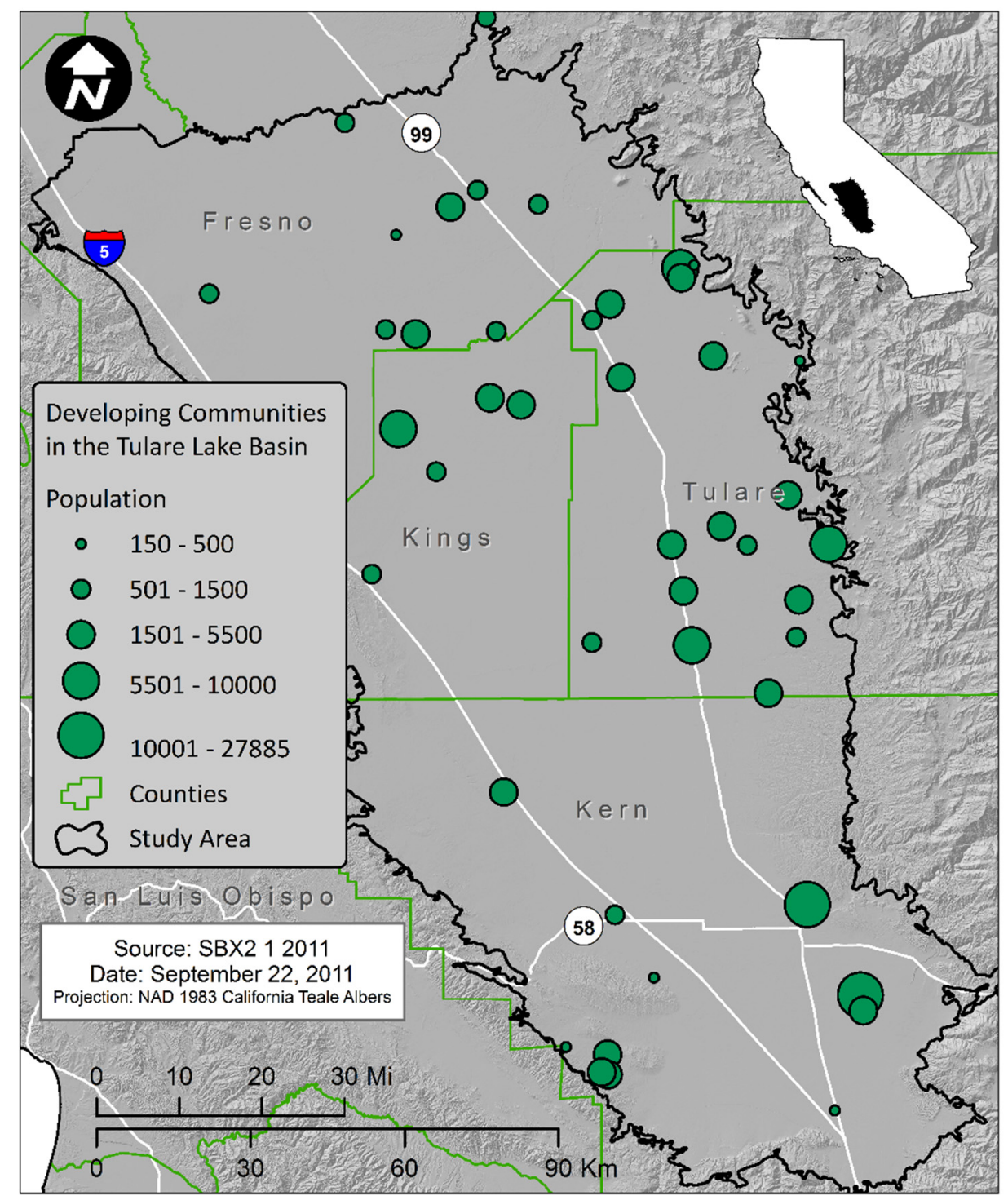

Figure 1. Developing Communities of the Tulare Lake Basin, California, CA, USA.

\subsection{Data Sources, Aggregation, and Analysis}

All spatial analyses were based on the California Augmented Multisource Landcover (CAML), which provides a detailed digital map of land use, in over 200 categories including over 80 agricultural crop categories [74]. The residential zone of each DC was spatially identified within the 2008 CAML map. Radial buffers were generated around the largest contiguous community zone of each DC (that is, not including outlying community areas) for buffer widths $x=500 \mathrm{~m}, 1000 \mathrm{~m}, 2000 \mathrm{~m}$, and $4000 \mathrm{~m}$. Records of the type and area of land use occurring within each buffer were extracted from the CAML map (Figure 2), 
along with the associated annual agricultural revenue, $\mathrm{NO}_{3}$ fertilizer application rate in $\mathrm{kg} \cdot \mathrm{N} \cdot \mathrm{ha}^{-1}$, and leaching loss in $\mathrm{kg} \cdot \mathrm{N} \cdot \mathrm{ha}^{-1}$ (Figure 3). Non-matching records (where CAML showed a crop area for which the California Agricultural Commissioner reported no revenue) and non-agricultural records were eliminated. Two DCs were excluded from the analysis since only animal production existed within a $4 \mathrm{~km}$ range (per-area revenues for animal production were not reported by [75]). One DC showed no revenue-producing agricultural production within $4 \mathrm{~km}$ vicinity and was thus also excluded from the analysis. Summary statistics of agricultural revenue, $\mathrm{kg} \cdot \mathrm{N} \cdot \mathrm{ha}^{-1}$ applied, and $\mathrm{kg} \cdot \mathrm{N} \cdot \mathrm{ha}^{-1}$ leached were generated for each of the four buffer widths for all remaining 44 DCs.

Median household income data from 2000 and population density data for 2010 for each DC were collected from the US Census Bureau [71]. Correlative analyses (JMP9, SAS Institute, Cary, NC, USA) were used to determine relationships between buffer size and the fertilizer application rate, or the revenue rate within each of the four buffers surrounding each DC. Water quality data of public (community) supply wells for 1985-2010 were obtained from the State of California [76].
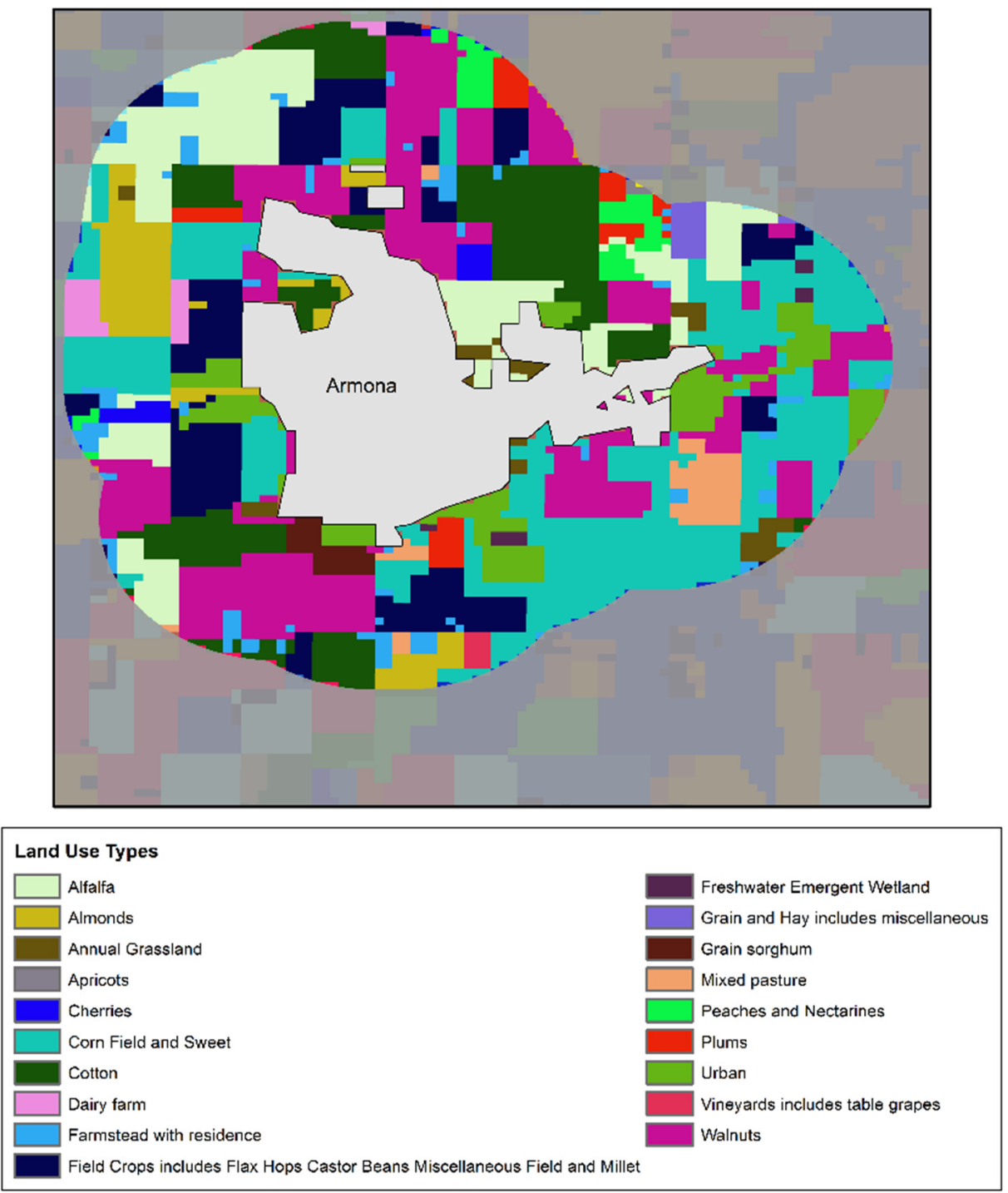

Figure 2. Landuses occuring within a sample $1000 \mathrm{~m}$ buffer zone. 


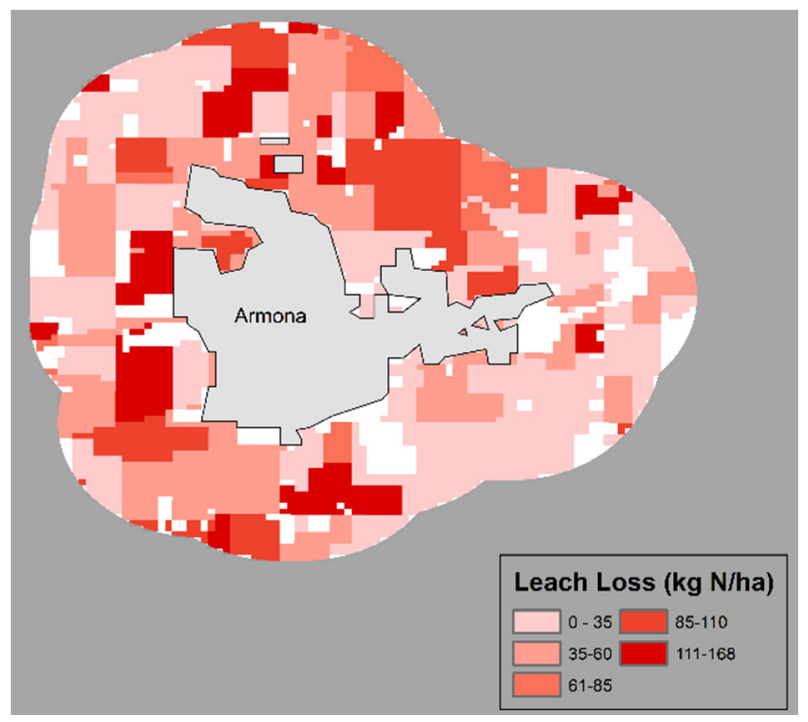

Figure 3. Nitrate leaching loss to groundwater $\left(\mathrm{kg} \cdot \mathrm{ha}^{-1}\right)$ occuring within a sample $1000 \mathrm{~m}$ buffer zone.

Nitrate leaching from crops was estimated using the analysis by [58]. In addition, information from the Central Valley Regional Water Board's dairy regulatory program [77] was utilized to identify animal production facilities and their manure application area within the buffer zone area. Nitrate leaching from dairy-owned land used for manure application is accounted for separately and was assumed to be $400 \mathrm{~kg} \cdot \mathrm{N} \cdot \mathrm{ha}^{-1} \cdot \mathrm{yr}^{-1}[59]$.

The Statewide Agricultural Production Model (SWAP) [78] base dataset was used as a data source for annual revenue per hectare of each production type. Given that the actual revenue of a crop group, such as grapes, depends greatly on the precise crop type (for example, wine grapes generate significantly more revenue than table grapes), SWAP employs weighted averages by crop group. The crop and other land use classes from 2008 CAML were matched with the 20 crop groups in SWAP for the state of California. Animal production facilities are not included in SWAP. Annual agricultural revenue per farmed area was joined to land use data from the 2008 CAML using Geographic Information Systems (GIS) [79] as described in [59].

\subsection{Economic Analysis of Land Buffers Conversion}

An input-output model for the study region was employed to assess the economic impact of land use conversion to buffer zones. Input-output analysis was first introduced by Leontief in the 1940s. It creates a mathematical description of the movements of products and services within an economy ([80], p. 16). A regional economy includes multiple economic sectors (such as agriculture and manufacturing, services and others), institutions (such as households and governments), and imports and exports. In an input-output model, each of these has an account in what is known as a Social Accounting Matrix (SAM). Impact analysis includes direct, indirect and induced effects. When a direct change occurs in one of the sectors (e.g., agriculture), this will have a spillover effect on the rest of the region's economy. The spillover effect consists of indirect and induced effects. Indirect effects capture purchases from the sector affected by the direct impact by sectors that serve as providers of production inputs. Direct effects correspond to the initial change in revenues from the policy or scenario to be modeled. 
In the case of agriculture, spillover effects include fertilizer purchases, irrigation water fees, and electricity bills, among others. Once these sectors have changed the payroll and profits for business owners, induced effects arise by purchases of the households whose members see a change in their labor and proprietary income. In turn, this affects consumer demand for purchase of goods and services within the region and imported from other regions. These interactions are mapped within the SAM. The indirect and induced effects are also known as multiplier effects. Usually, the multiplier effects of labor-intensive sectors (like agriculture) result in multipliers for employment that are larger than those for total revenues.

In this study, we examined the potential impacts on agricultural revenues from buffer land use conversion (direct effect). Sectors that provide production inputs and services also see changes in their revenues (indirect effect). Households that receive income from agriculture and all other activities in the region also experience a change in their income (induced effect). The total of these effects are estimated as revenues (or sector output), employment, and labor income. Sector output is often referred as total sales or revenues from one sector; "labor income" comprises employee compensation and proprietary income; "employment" represents all jobs in the regional economy, including part-time jobs.

We employed the IMPLAN (MIG, Minneapolis, USA) model [81], an economic multiplier model built from non-survey data, to assess the economic impact of land use conversion to buffers. IMPLAN was used to analyze the effect of designating current cropland as recharge buffer zones, with concomitant changes in land use. Multiplier models provide a snapshot of a region's economy via quantitative mapping of interrelationships among production sectors and institutions as mentioned earlier. In this case, IMPLAN takes changes in revenues for one or more sectors and provides direct, indirect and induced changes in sector output, employment, and value added. Results are identified as either direct or multiplier effects. By providing IMPLAN with estimates of changes in sector output of crop farming (i.e., North American Industry Classification System (NAICS) sector 111) [82], it is possible to obtain estimates of indirect and induced changes in all other sectors in the regional economy. See Table 1 for a complete description of the categorization of impacts in IMPLAN.

Table 1. Categorization of impacts in IMPLAN.

\begin{tabular}{|c|c|c|}
\hline Impact Type & Description & Role/Impact \\
\hline Direct effects & $\begin{array}{l}\text { The set of expenditures applied to the } \\
\text { predictive model (i.e., I/O multipliers) } \\
\text { for impact analysis. It is one } \\
\text { (or a series of) production change(s) } \\
\text { or expenditure(s) made by } \\
\text { producers/consumers as a result of an } \\
\text { activity or policy }\end{array}$ & $\begin{array}{l}\text { These initial changes are determined by an analyst to } \\
\text { be a result of this activity or policy. Applying these } \\
\text { initial changes to the multipliers in an IMPLAN } \\
\text { model will then display how the region will } \\
\text { economically respond to these initial changes. }\end{array}$ \\
\hline $\begin{array}{l}\text { Indirect } \\
\text { effects }\end{array}$ & $\begin{array}{l}\text { The impact of local industries } \\
\text { buying goods and services } \\
\text { from other local industries. }\end{array}$ & $\begin{array}{l}\text { The cycle of spending works its way backward } \\
\text { through the supply chain until all money leaks from } \\
\text { the local economy, either through imports } \\
\text { or by payments to value added. }\end{array}$ \\
\hline $\begin{array}{l}\text { Induced } \\
\text { effects }\end{array}$ & $\begin{array}{l}\text { The response by an economy to an initial } \\
\text { change (direct effect) that occurs } \\
\text { through re-spending of income received } \\
\text { by a component of value added. }\end{array}$ & $\begin{array}{l}\text { IMPLAN's default multiplier recognizes that labor } \\
\text { income (employee compensation and proprietor } \\
\text { income components of value added) is not leaked to } \\
\text { the regional economy. This money is recirculated } \\
\text { through household spending patterns, causing further } \\
\text { local economic activity. }\end{array}$ \\
\hline
\end{tabular}


A model of the Tulare Lake Basin was created using the 2007 IMPLAN database. Counties include

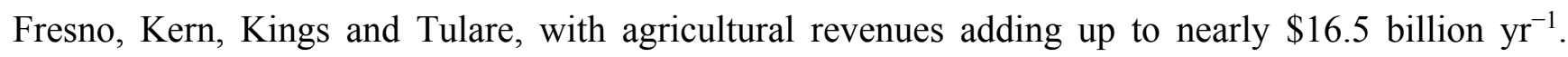
Establishment cost estimates for vineyards average \$16,000/acre (for the first three years), and for alfalfa around $\$ 825 /$ acre. The values of agricultural crop land uses for a range of land use buffers were estimated.

\section{Results}

\subsection{Developing Communities and Current Water Quality}

In the TLB, $6 \%$ of the population $(155,000)$ lives in 44 developing communities (Table 2). The median household income is $\$ 26 \mathrm{k}$-about $\$ 20 \mathrm{k}$ less than in the NDACs of the same region. Population density, while highly variable, is 2.5 times higher in DCs than in NDACs. A review of raw water quality (prior to any treatment) in public supply well records collocated within 1 mile of the identified DCs shows that 40 of 44 DCs have a total of 278 public supply wells (wells with at least 15 connections), of which 69 (25\%) have exceeded the MCL for $\mathrm{NO}_{3}$ at least once and for 32 wells $(12 \%)$ the average of reported $\mathrm{NO}_{3}$ level is above the MCL. In 24 DCs the maximum measured nitrate level exceeds the MCL, in 16 DCs at least one well has an average $\mathrm{NO}_{3}$ concentration that is above the MCL, in 2 DCs, the median measured nitrate level among all wells exceeds the MCL. Only 9 of 40 DCs with public supply wells have maximum observed $\mathrm{NO}_{3}$ levels that have always stayed below $18 \mathrm{mg} \cdot \mathrm{L}^{-1}$, which is considered the threshold value for anthropogenic influence [63]. Most of these DCs are located in the western TLB, where supply wells are typically completed below a naturally occurring protective clay aquitard. No complete datasets are available for small community system wells with less than 15 connections.

Table 2. US Census Bureau 2000 Annual Household Income (USD $\mathrm{yr}^{-1}$ ) and 2010 Population Census Data for all DCs and NDACs. DC: developing community; NDAC: non-disadvantaged community.

\begin{tabular}{c|ccc|ccc|cccc}
\hline \multirow{2}{*}{$\begin{array}{c}\text { Community } \\
\text { type }\end{array}$} & \multicolumn{3}{|c|}{ Household Income } & \multicolumn{4}{c|}{ Population Density } & \multicolumn{4}{c}{ Population } \\
\cline { 2 - 11 } & Median & Min & Max & Median & Min & Max & Median & Min & Max & Total \\
\hline DC & $\$ 26,379$ & $\$ 19,838$ & $\$ 37,684$ & 410 & 47 & 2462 & 1951 & 106 & 32,684 & 154,500 \\
NDAC & $\$ 46,797$ & $\$ 38,594$ & $\$ 76,277$ & 160 & 17 & 2368 & 799 & 115 & 17,560 & 48,125 \\
\hline
\end{tabular}

\subsection{Buffer Effects on Fertilizer, Leaching Loss, and Revenue Rates}

The total buffer size around the 44 DCs varies from 26,000 ha to nearly 300,000 ha for buffer width ranging from $500 \mathrm{~m}$ to $4000 \mathrm{~m}$. Within these buffers, cropland area, considered to be the recharge area, varies from 11,000 ha to 210,000 ha for the four buffer zones (Table 3). Total revenue within these four buffers varies from $\$ 90$ million to $\$ 1,700$ million with the largest share in subtropical fruits, tree fruits, and nuts (Table 4). We found no significant variations in fertilizer applied per hectare, leaching loss per hectare, nor revenue per hectare between the four selected buffer regions, regardless of MHI or county. Applying Equation (2), the estimated recharge source area of these DCs is nearly 14,000 ha. Within the $1000 \mathrm{~m}$ buffer width, the total current cropland area is 27,230 ha, twice the size of the minimum estimated 
well source area for these DCs. The $1000 \mathrm{~m}$ buffer (Figure 2) would therefore sufficiently account for aquifer heterogeneity, transient groundwater flow, and uncertainty in determining the well source area. Hence, only the $1000 \mathrm{~m}$ buffer was used for further analyses.

Table 3. Land area (ha) within each buffer zone.

\begin{tabular}{ccccc}
\hline Land Use & $\begin{array}{c}\mathbf{5 0 0} \mathbf{~ m} \\
\text { Buffer Zone }\end{array}$ & $\begin{array}{c}\mathbf{1 0 0 0 ~} \\
\text { Buffer Zone }\end{array}$ & $\begin{array}{c}\mathbf{2 0 0 0} \mathbf{~ m} \\
\text { Buffer Zone }\end{array}$ & $\begin{array}{c}\mathbf{4 0 0 0} \mathbf{~ m} \\
\text { Buffer Zone }\end{array}$ \\
\hline Cropland & 11,263 & 27,230 & 73,040 & 209,699 \\
Natural land and pasture & 2888 & 6190 & 15,546 & 49,259 \\
Urban & 11,387 & 14,095 & 19,718 & 33,083 \\
Dairy Facilities and other farmsteads & 257 & 617 & 1717 & 5458 \\
Area of cropland receiving manure & 680 & 1542 & 4587 & 17,277 \\
Total & $\mathbf{2 5 , 7 9 4}$ & $\mathbf{4 8 , 1 3 2}$ & $\mathbf{1 1 0 , 0 2 1}$ & $\mathbf{2 9 7 , 4 9 9}$ \\
\hline
\end{tabular}

Table 4. Estimated agricultural value for various land use buffer sizes, using crop and yields from the SWAP model [77].

\begin{tabular}{ccccc}
\hline \multirow{2}{*}{ Crop Groups } & \multicolumn{3}{c}{ Gross Agricultural Crop Annual Revenues by Buffer Size } \\
& \multicolumn{4}{c}{ (Millions $\mathbf{\$ 2 0 0 7})$} \\
\cline { 2 - 5 } & $\mathbf{5 0 0 ~} \mathbf{~}$ & $\mathbf{1 0 0 0} \mathbf{~ m}$ & $\mathbf{2 0 0 0} \mathbf{~ m}$ & $\mathbf{4 0 0 0} \mathbf{~ m}$ \\
\hline Field crops and grain & 9.1 & 22.9 & 61.7 & 178.7 \\
Subtropical fruit and vineyards & 17.4 & 39.7 & 100.8 & 275.2 \\
Tree Fruits and Nuts & 53.1 & 130.9 & 362.0 & $1,021.2$ \\
Pasture and Forages & 4.4 & 10.4 & 26.3 & 75.5 \\
Vegetables and berry crops & 6.2 & 15.0 & 44.2 & 115.8 \\
\hline Total & $\mathbf{9 0 . 2}$ & $\mathbf{2 1 8 . 9}$ & $\mathbf{5 9 5 . 0}$ & $\mathbf{1 , 6 6 6 . 5}$ \\
\hline
\end{tabular}

Note: ${ }^{1}$ Subtropical fruit is almost exclusively citrus.

Currently, cropland in the $1000 \mathrm{~m}$ buffer area receives $3396 \mathrm{Mg}$ of $\mathrm{N}$ fertilizer annually (Table 5). After accounting for harvest, runoff losses $\left(14 \mathrm{~kg} \cdot \mathrm{N} \cdot \mathrm{ha}^{-1} \cdot \mathrm{yr}^{-1}\right)$, atmospheric deposition $\left(10 \mathrm{~kg} \cdot \mathrm{N} \cdot \mathrm{ha}^{-1} \cdot \mathrm{yr}^{-1}\right)$, irrigation water $\mathrm{N}\left(22 \mathrm{~kg} \cdot \mathrm{N} \cdot \mathrm{ha}^{-1} \cdot \mathrm{yr}^{-1}\right)$, and atmospheric losses (10\%) [58], an estimated $45 \%$ of the applied $\mathrm{N}$ leaches out of the soil into groundwater, at an average rate of $56 \cdot \mathrm{kg} \cdot \mathrm{N} \cdot \mathrm{ha}^{-1} \cdot \mathrm{yr}^{-1}$; this amounts to $10 \mathrm{~kg} \mathrm{~N} \cdot \mathrm{yr}^{-1}$ per DC person leaching out of the soil into the aquifer. Existing agricultural land use with higher risk for nitrate contamination include citrus, tree fruit and nut crops, and dairy facilities and their cropland [16]. Citrus cops currently constitute $13 \%$ of the cropland in the $1000 \mathrm{~m}$ buffer zone, while tree fruit and nuts currently constitute $18 \%$. Together, they account for nearly one third of all groundwater nitrate leaching. About $6 \%$ of cropland (mostly corn) in the $1000 \mathrm{~m}$ buffer currently is receiving dairy manure likely leading to excess groundwater nitrate leaching (about one-quarter of all nitrate leaching in the $1000 \mathrm{~m}$ buffer, Table 5). On the other hand, alfalfa and vineyards (including table grapes) constitute $30 \%$ of all cropland, but only contribute $11 \%$ of groundwater nitrate (Table 5). The latter two crops are the only crops not exceeding the $35 \mathrm{~kg} \cdot \mathrm{N} \cdot \mathrm{ha}^{-1} \cdot \mathrm{yr}^{-1}$ threshold that likely leads to nitrate contamination. Corn also has lower leaching, but is the main crop responsible for leaching from excess manure applications, accounted for separately $[58,59]$. 
Table 5. $2008 \mathrm{~N}$ fertilizer applied and estimated leachate per hectare within $1000 \mathrm{~m}$ buffer zone around a DAC or SDAC census designated place.

\begin{tabular}{|c|c|c|c|c|c|c|c|c|}
\hline Agricultural Land Use & Area & $\begin{array}{c}\text { Synthetic } \\
\text { Fertilizer N }\end{array}$ & Harvested N & $\begin{array}{c}\text { Ground-Water } \\
\text { Leaching N }\end{array}$ & Area & $\begin{array}{c}\text { Synthetic } \\
\text { Fertilizer N }\end{array}$ & Harvested N & $\begin{array}{c}\text { Ground-Water } \\
\text { Leaching N }\end{array}$ \\
\hline Subtropical & 3455 & 103 & 55 & 57 & $13 \%$ & $11 \%$ & $6 \%$ & $9 \%$ \\
\hline Nuts & 2398 & 177 & 94 & 81 & $9 \%$ & $12 \%$ & $7 \%$ & $9 \%$ \\
\hline Cotton & 3579 & 191 & 86 & 101 & $13 \%$ & $20 \%$ & $9 \%$ & $17 \%$ \\
\hline Corn & 2381 & 235 & 221 & 6 & $9 \%$ & $16 \%$ & $16 \%$ & $1 \%$ \\
\hline Alfalfa & 3060 & 12 & 436 & 30 & $11 \%$ & $1 \%$ & $40 \%$ & $4 \%$ \\
\hline Vegetables and berries & 1254 & 205 & 84 & 115 & $5 \%$ & $8 \%$ & $3 \%$ & $7 \%$ \\
\hline Vineyards & 5181 & 37 & 17 & 31 & $19 \%$ & $6 \%$ & $3 \%$ & $7 \%$ \\
\hline $\begin{array}{l}\text { Additional manure } \mathrm{N} \text { on dairy } \\
\text { cropland (corn) }\end{array}$ & 1542 & - & - & 400 & - & - & - & $28 \%$ \\
\hline
\end{tabular}




\subsection{Estimated Costs of Land Use Buffers}

Results indicate a wide range of change in direct revenues from current crop farming to conversion to a buffer zone (Tables 6-9). Of more interest, however is the net effect after retiring current production and converting to buffer land use, which results in a loss revenue stream from current crops and new revenue streams from alternative land uses. Tables 6-8 show the net changes in total sector output, employment and value added for the various combinations of recharge basins, alfalfa, and vineyard land use in a redesigned buffer zone. At the extremes, buffers are either all alfalfa or all vineyards with $1 \%$, $3 \%$ or $10 \%$ of the buffer area devoted to recharge basins. Having all land use converted to vineyards is the most profitable. In general, as the split of available buffer land between recharge basins, alfalfa, and vineyards becomes more alfalfa intensive, changes in sector output, employment and value added become less, leading to net losses when large areas are converted to alfalfa.

Table 6. Direct revenue in alternative recharge buffer zones at varying recharge basin areas and for various combinations of alfalfa/vineyard splits in a $1000 \mathrm{~m}$ land use buffer (compare to Table 4 for current revenue).

\begin{tabular}{cccccccc}
\hline \multirow{2}{*}{$\begin{array}{c}\text { Recharge Basins } \\
\text { (\% of Buffer Zone) }\end{array}$} & \multicolumn{5}{c}{ Alfalfa/Vineyard split (\% of Remaining Buffer Zone Area) } \\
\cline { 2 - 8 } Annual Direct Revenue (Sector Output) & Gains (in Million \$ 2007) \\
\hline & $\mathbf{0 / 1 0 0}$ & $\mathbf{1 0 / 9 0}$ & $\mathbf{3 3 . 6 / 6 6 . 6}$ & $\mathbf{5 0 / 5 0}$ & $\mathbf{6 6 . 7 / 3 3 . 3}$ & $\mathbf{9 0 / 1 0}$ & $\mathbf{1 0 0 / 0}$ \\
\hline $1 \%$ & 279.2 & 259.9 & 214.7 & 182.5 & 150.3 & 105.1 & 85.8 \\
$3 \%$ & 273.6 & 254.6 & 210.4 & 178.8 & 147.2 & 103.0 & 84.1 \\
$10 \%$ & 253.8 & 236.2 & 195.2 & 165.9 & 136.6 & 95.6 & 78.0 \\
\hline
\end{tabular}

Table 7. Direct and total changes in sector output for Table 6 scenarios in a $1000 \mathrm{~m}$ land use buffer.

\begin{tabular}{ccccccccc}
\hline Effects & \% Recharge Basins & $\mathbf{0 / 1 0 0}$ & $\mathbf{1 0 / 9 0}$ & $\mathbf{3 3 . 3 / 6 6 . 7}$ & $\mathbf{5 0 / 5 0}$ & $\mathbf{6 6 . 7 / 3 3 . 3}$ & $\mathbf{9 0 / 1 0}$ & $\mathbf{1 0 0 / 0}$ \\
\hline \multirow{2}{*}{ Net direct effects } & $\mathbf{1 \%}$ & 73.0 & 53.6 & 8.5 & -23.7 & -56.0 & -101.1 & -120.4 \\
(million \$ 2007) & $\mathbf{3 \%}$ & 67.4 & 48.4 & 4.2 & -27.4 & -59.0 & -103.2 & -122.2 \\
& $\mathbf{1 0 \%}$ & 47.6 & 30.0 & -11.0 & -40.3 & -69.6 & -110.6 & -128.2 \\
\hline \multirow{2}{*}{ Net total effects } & $\mathbf{1 \%}$ & 125.7 & 92.4 & 14.7 & -40.8 & -96.3 & -174.0 & -207.3 \\
(million \$ 2007) & $\mathbf{3 \%}$ & 115.9 & 83.3 & 7.2 & -47.2 & -101.6 & -177.7 & -210.3 \\
& $\mathbf{1 0 \%}$ & 82.0 & 51.7 & -18.9 & -69.4 & -119.8 & -190.5 & -220.7 \\
\hline
\end{tabular}

Table 8. Direct and total effects of Table 6 scenarios on employment in a $1000 \mathrm{~m}$ land use buffer.

\begin{tabular}{ccccccccc}
\hline Effects & \% Recharge Basins & $\mathbf{0 / 1 0 0}$ & $\mathbf{1 0 / 9 0}$ & $\mathbf{3 3 . 3 / 6 6 . 7}$ & $\mathbf{5 0 / 5 0}$ & $\mathbf{6 6 . 7 / 3 3 . 3}$ & $\mathbf{9 0 / 1 0}$ & $\mathbf{1 0 0 / 0}$ \\
\hline \multirow{2}{*}{ Net direct } & $\mathbf{1 \%}$ & 423 & 311 & 49 & -138 & -325 & -586 & -698 \\
effects (jobs) & $\mathbf{3 \%}$ & 391 & 281 & 24 & -159 & -342 & -599 & -709 \\
& $\mathbf{1 0 \%}$ & 276 & 174 & -64 & -234 & -404 & -642 & -744 \\
\hline \multirow{2}{*}{ Net total } & $\mathbf{1 \%}$ & 971 & 714 & 113 & -315 & -744 & -1344 & -1602 \\
effects (jobs) & $\mathbf{3 \%}$ & 896 & 644 & 56 & -365 & -785 & -1373 & -1625 \\
& $\mathbf{1 0 \%}$ & 633 & 399 & -146 & -536 & -926 & -1472 & -1705 \\
\hline
\end{tabular}


Table 9. Direct and total effects of Table 6 scenarios on labor income of a $1000 \mathrm{~m}$ land use buffer.

\begin{tabular}{ccccccccc}
\hline Effects & $\mathbf{\%}$ Recharge Basins & $\mathbf{0 / 1 0 0}$ & $\mathbf{1 0 / 9 0}$ & $\mathbf{3 3 . 3 / 6 6 . 7}$ & $\mathbf{5 0 / 5 0}$ & $\mathbf{6 6 . 7 / 3 3 . 3}$ & $\mathbf{9 0 / 1 0}$ & $\mathbf{1 0 0 / 0}$ \\
\hline \multirow{2}{*}{ Net direct effects } & $\mathbf{1 \%}$ & 16.0 & 11.8 & 1.9 & -5.2 & -12.3 & -22.1 & -26.4 \\
(million \$ 2007) & $\mathbf{3 \%}$ & 14.8 & 10.6 & 0.9 & -6.0 & -12.9 & -22.6 & -26.8 \\
& $\mathbf{1 0 \%}$ & 10.4 & 6.6 & -2.4 & -8.8 & -15.3 & -24.2 & -28.1 \\
\hline \multirow{2}{*}{ Net total effects } & $\mathbf{1 \%}$ & 33.6 & 24.7 & 3.9 & -10.9 & -25.7 & -46.5 & -55.4 \\
(million \$ 2007) & $\mathbf{3 \%}$ & 31.0 & 22.3 & 1.9 & -12.6 & -27.1 & -47.5 & -56.2 \\
& $\mathbf{1 0 \%}$ & 21.9 & 13.8 & -5.1 & -18.5 & -32.0 & -50.9 & -59.0 \\
\hline
\end{tabular}

With all buffer area devoted to vineyards, net direct gains are as large as $\$ 73$ million $\mathrm{yr}^{-1}$ in sector output (with $1 \%$ of buffer zone dedicated to recharge basins) and $\$ 126$ million $\cdot \mathrm{yr}^{-1}$ when the direct, indirect and induced effects are taken into account. In this case, total employment gains reach 971 jobs, with an increase in labor income of about $\$ 33.6$ million $\cdot \mathrm{yr}^{-1}$. In contrast, devoting $10 \%$ of the buffer area to recharge basins and dedicating the rest of the area to alfalfa (right most column in Tables 6-8), total sector output losses are $\$ 220$ million $\cdot \mathrm{yr}^{-1}$, with up to $\$ 59$ million losses in labor income.

Importantly, the break-even point for land use within the buffers (wherein the area remains economically equivalent to its current state) occurs when about $3 \%$ of buffer areas are dedicated to recharge basins and at least two-thirds of the remaining buffer zone is in vineyards, a more than three-fold increase in vineyard area when compared to current land use. In contrast, the control scenario (permanent fallow) would result in significant agricultural revenue losses, averaging \$206 million $\mathrm{yr}^{-1}$; this represents about $1.3 \%$ of the more than $\$ 16$ billion [75] generated by the four counties within which the study area falls. Indirect and induced effects would increase average total losses in sector output to $\$ 355$ million.

\subsection{Estimated Cost of Conversion}

Changing land use in the buffers is likely to have significant establishment costs. For a 20 hectare alfalfa farm, the average cost for establishing alfalfa is roughly $\$ 3,140 /$ hectare [83]. Vineyards have much higher establishment costs, estimated to be $\$ 38,780 /$ hectare for a 25 hectare contiguous field [84]. Recharge basin installation and operating costs is on the order of $\$ 20,000 /$ hectare annualized [85]. However, supplemental surface water used for recharge in the buffers may help prevent or alleviate flood damage; flood damage from the Kings and San Joaquin Rivers is estimated at $\$ 740$ million since 1983 [67,86]. Benefits from avoided damage costs elsewhere are yet to be estimated; however, the calculations used here account for flood damage avoidance costs. For the Central Valley Flood Protection Program [87] damage and flooding costs as expected annual damages (EAD) are estimated using U.S. Army Corps of Engineers (USACE) Hydrologic Engineering Center Flood Damage Analysis (HEC-FDA) model. EAD include structure and content damages, crop damages, business income, and production losses. Benefits from flood protection are obtained as the difference between the EAD with and without flood protection project. Approximately $7 \%$ and $9 \%$ of the Tulare Lake Basin are already under alfalfa and vineyard production, respectively. Preliminary analyses showed no variation in crop coverage with proximity to a community. Therefore, these percentages were assumed to be representative of buffer areas when calculating conversion costs. Accounting for existing fields within buffer zones (including replacing alfalfa with vineyard and vice versa as needed), estimated cost of 
conversion to a vineyard/alfalfa/recharge basin model range from $\$ 206$ million to $\$ 2.73$ billion for all DC $1000 \mathrm{~m}$ buffer zones in the study area (Table 10). When divided between the DCs, the estimated cost would range from $\$ 3.4$ million to $\$ 44.8$ million per community, with alfalfa-intensive scenarios at the lower end of the scale. When sector output gains (Table 6) over 20 years and potential cost saving through flood control over 20 years are considered, costs are completely offset and gains ranging from $\$ 2.3$ billion to 5 billion for the entire study are (or $\$ 37.4$ million to $\$ 82.1$ million per community) are indicated. In comparison, drinking water treatment would currently add between $\$ 17$ and $\$ 35$ million $\mathrm{yr}^{-1}$ (0.34 to 0.7 billion over 20 years) to federal cost.

Table 10. Estimated cost of conversion to various proposed recharge buffer zone scenarios.

\begin{tabular}{cccccccc}
\hline \multirow{2}{*}{$\begin{array}{c}\text { Recharge Basins } \\
\text { (\% of Buffer Zone) }\end{array}$} & \multicolumn{7}{c}{$\begin{array}{c}\text { Alfalfa/Vineyard Split (\% of Remaining Buffer Zone Area) } \\
\text { Cost of Conversion (Billion \$) }\end{array}$} \\
\cline { 2 - 8 } & $\mathbf{0 / 1 0 0}$ & $\mathbf{1 0 / 9 0}$ & $\mathbf{3 3 . 6 / 6 6 . 6}$ & $\mathbf{5 0 / 5 0}$ & $\mathbf{6 6 . 7 / 3 3 . 3}$ & $\mathbf{9 0 / 1 0}$ & $\mathbf{1 0 0 / 0}$ \\
\hline $1 \%$ & 2.73 & 2.44 & 1.80 & 1.34 & 0.87 & 0.23 & 0.23 \\
$3 \%$ & 2.68 & 2.40 & 1.76 & 1.31 & 0.86 & 0.23 & 0.23 \\
$10 \%$ & 2.48 & 2.21 & 1.63 & 1.21 & 0.79 & 0.21 & 0.23 \\
\hline
\end{tabular}

\section{Discussion}

\subsection{Determining Local Appropriateness of Application}

Our results indicate that recharge buffer zones designed to effectively reduce local $\mathrm{NO}_{3}$ contamination of drinking water sources can be implemented without undermining the regional economy. The feasibility of implementing buffer zones also depends on each community's ability to access funding sources, implement policy options, and existing natural resources, infrastructure, and stakeholder perceptions. Consequently, recharge buffer zones should be viewed as one option among a portfolio of options that communities may consider in addressing agricultural water contamination issues.

Recharge buffer zones may be a particularly attractive option for communities facing significant financial constraint. While they are not without implementation cost (about \$233,000/hectare), the majority of the expense of recharge buffers occurs as an initial up-front investment; once they have

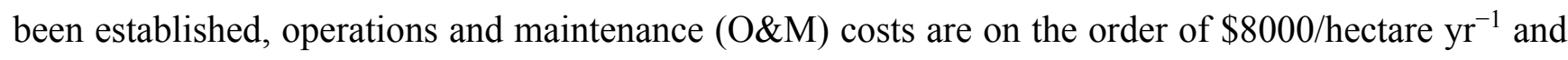
can be transferred into the farming operation. In this regard, recharge buffers hold a unique advantage over water treatment plant options, which require both a large initial installation investment, as well as significant O\&M. In addition, available capacity for implementing water treatment O\&M is small. Available state and federal support (California State Revolving Fund) may provide loans or grants for the initial implementation costs, but does not provide O\&M funding. Consequently, the up-front costs of recharge buffers could be largely supported by the state. In contrast, the O\&M for water treatment plants often is a significant burden on the community.

Recharge buffer zones are a particularly good fit for agricultural communities because labor capacity already exists to support crop production and irrigation. Also, much of the infrastructure needed to implement recharge buffers already exists in agricultural communities. Implementation of recharge buffer zones may create additional uses — and benefits — for existing community activities and resources. The utilization 
of existing community capacity, rather than seeking to import the skills and resources necessary for water treatment options, would minimize project impact on the community structure.

Finally, recharge buffer zones may be a good fit for communities attracted to the idea of prophylactically remediating their groundwater at the source of the problem, rather than using a "Band-Aid" treatment option to mask the problem. Recharge buffer zone projects appeal to environmental protection and environmental justice organization that may offer additional support and funding for assisting the community's effort (see Section 4.4).

\subsection{Complementary Policy Options}

Buffer zone size and area should be determined on a case-by-case basis using hydrogeological expertise. Preliminary calculations of the community's water needs and the well source area $A_{\mathrm{s}}$ (Section 2.2) will inform decisions regarding the minimum quantity of clean recharge water that the buffer zone must supply. Prevailing local groundwater conditions, ownership and agronomic limitations, and resource availability may also affect the buffer area size determination. Likewise, a community with a large calculated $A_{\mathrm{s}}$ and a relatively large local supply of clean water may choose to create a smaller recharge zone with an augmented, high recharge rate. Consideration of projected population growth and urban development is likely to affect future land use; as this change in land use will likely result in a negligible change in nitrate leaching [59], it may compromise land use management efforts aimed at establishing recharge buffers. Thus a significant challenge to counties and DCs is to actively integrate recharge and nitrate reduction into land use planning.

Once the optimal recharge zone size and recharge rate have been determined, governing authorities, private parties, or NGOs have the option to either acquire the land within the identified buffer zone, or to begin mandated and/or incentivized programs with farmers that own that land. In the case where public ownership is sought, land may be leased back to farmers with specific requirements to meet land use and recharge quality and quantity restrictions, as modeled by Rudolph [34]. Incentivized programs (e.g., funded through state-support) may involve, for example, credits given to farmers for enrolling in long-term conversion of farm land and for maintaining certain land use practices that minimize use of $\mathrm{N}$ fertilizer (and other agro-chemicals); for communities with severe economic restrictions, this may be a less expensive alternative to either treating contaminated water or purchasing land for lease-back within recharge buffer zones.

Regardless of land ownership, government regulations may be established regarding the utilization of the recharge zones and how the requisite clean recharge minimums will be met. These decisions may be influenced according to prevailing local needs, limitations, and resources, and may evolve as groundwater $\mathrm{NO}_{3}$ concentrations and local needs change. For example, communities with tourism potential or those with highly $\mathrm{NO}_{3}$-contaminated water may elect to create managed wetlands, which can serve simultaneously as recharge basins, recreational spaces, and natural denitrification facilities.

\subsection{Additional Planning and Design Considerations}

Other issues that need to be considered in the planning and implementation of buffer zones dedicated to clean recharge include the infrastructure needed to deliver additional irrigation/recharge water in excess of water needs under current crop irrigation practices into the buffer zone. Delivery of additional 
surface water or delivery of surface water during months not traditionally used for irrigation may require some augmented canal or pipeline capacity, altered maintenance schedules on irrigation water networks, adjustments in the water management within the buffer zone, or a combination thereof. However, unlike direct use of (treated) surface water as drinking water source, the maintenance of additional, high quality recharge neither requires treatment nor continuous, year-round access to surface water supplies (many existing agricultural surface supply systems require annual shut down for maintenance).

Local water rights may also pose significant challenges, particularly if the conversion to a buffer zone involves changing the amount of surface water applied within the buffer zone. If additional recharge is achieved, questions of ownership, monitoring, and management of banked groundwater credits may need to be addressed depending on local or state water law.

The management of agricultural lands for increased high quality recharge of water to a groundwater basin within a designated buffer zone requires minimizing the leaching of agricultural chemicals while keeping with agronomic objectives for crop health and productivity. This may include redesigning irrigation systems (e.g., recharging along a narrow strip in the middle of vineyard rows), alternate irrigation scheduling, and careful co-management of water, fertilizer and pesticide application $[67,86]$. Integration of multiple approaches may be required for successful operation, yet, current research on such dual objectives in agricultural irrigation is extremely limited.

Finally, other local $\mathrm{NO}_{3}$ sources not considered here, but potentially occurring in source areas may warrant significant improvements to prevent groundwater contamination. In rural areas, this would primarily include attention to clusters of high density collocated septic systems and food processors.

\subsection{Limitations and Further Study}

The census and economic data used here provide only a snapshot in time of conditions in the study area. Year-to-year crop rotations and fallowing within farms, climactic events, and large-scale market shifts all affect employment and production on any given land area in any given year. Migration shifts, changes in household income, and the presence and conditions of illegal farm workers are not recorded by censuses. Proposed changes are likely to affect the agricultural system in ways not captured by the analysis. Similarly, the actual revenue of a CAML crop group, such as grapes, depends greatly on the precise crop type (i.e., quality, varietal, end use, etc.). The results of this study are thus best seen as representative rather than as fixed measures. Implementation of recharge buffer zones would add as much as 27,000 ha of alfalfa or vineyard production. The proposed magnitude of land use changes-if implemented across all DCs - constitutes a significant, but not uncommon change in crop acreage for alfalfa and vineyards: current harvested alfalfa and vineyard areas in the TLB are much larger, on the order 150,000 and 200,000 ha, respectively. Finally, the economic analysis may overestimate the effects of land use conversion: multiplier models such as IMPLAN assume that the economy is inflexible and thus there will not be adaptation. In reality, sectors other than agriculture may grow in response to these changes, therefore reducing the effect of land use conversion. Similarly, capital costs of converting land to vineyards may well offset net benefits of devoting land to this activity in the short run. Thus the economic analysis presented in this study represents a long-term estimate of the potential economic gains and losses associated with land use buffers. 
A significant source of nitrate not explicitly addressed here is dairy manure. New regulations for this industry are aiming at significantly reducing $\mathrm{NO}_{3}$ loading to groundwater, but it may be important to completely remove or significantly limit manure application within source areas. Also, here we do not consider moving or abandoning existing animal farming facilities within buffer zones, due to the high financial and political cost of doing so.

Importantly, creation of recharge buffer zones presents an intermediate to long-term fix to already contaminated groundwater. Depending on the depth of existing drinking water supply wells, the distance to recharge sources, recharge rates, and local hydrogeological conditions, improvements in water quality may not meet drinking water quality standards for several years (or even decades) into the future [88]. With smart design of intentional recharge operations, the time frame may be shortened. Yet, the effective delay requires that interim solutions be found in communities already affected by high $\mathrm{NO}_{3}$ in drinking water, an economic investment that further weighs into the analysis of long-term alternatives to address drinking water quality issues.

Further site-specific assessment of land use buffer zones would include hydrogeological, economic, and policy assessments on a community-by-community basis. These analyses would help determine project feasibility and design given each community's unique circumstances. The suitability of nitrate hazard/vulnerability indices in this endeavor may warrant special attention [30].

\section{Conclusions}

Our study of agricultural production in the Tulare Lake Basin indicated no relationships between proximity to a disadvantaged community and $\mathrm{N}$ fertilizer application, $\mathrm{N}$ leaching loss, or revenue rates. Given the pressing water quality circumstances in this region, we have explored the potential of establishing recharge buffers zones of $1000 \mathrm{~m}$ around developing communities to ameliorate very high drinking water $\mathrm{NO}_{3}$ concentrations. The size of the buffer zone is consistent with the estimated source area needed to provide groundwater as drinking water to these communities, given their population and local hydrogeological conditions. Within these buffer zones, citrus, tree fruit, and nut crops were found to account for about $33 \%$ of nitrate leaching to groundwater, and the $6 \%$ of cropland receiving dairy manure was found to account for about $25 \%$ of all nitrate leachate. The establishment of perennial and/or leguminous $\mathrm{N}$-fixing crops in combination with supplying clean groundwater recharge within the proposed buffer zones would reduce nitrate leaching to safe levels, and shows a wide range of change in direct revenues, with vineyards results in the greatest increases in profit. Land use changes are likely to have significant establishment costs; however, when sector gains and flood prevention or alleviation over 20 years are considered, gains range from 2 to 5 billion USD for the study area. In comparison, drinking water treatment would currently add between $\$ 17$ and $\$ 35$ million $\mathrm{yr}^{-1}$ to federal cost. Recharge buffer zones may be a particularly attractive option for communities facing significant financial constraint since the up-front costs of recharge buffers could be largely supported by state funding programs, and operation and maintenance costs are minimal. Given the intrinsic link between water security and human and environmental well-being, such changes in the use of land surrounding developing communities must be prioritized for implementation. 


\section{Acknowledgments}

Portions of this work were completed within the framework of the California Nitrate Project (SBX2 1), funded by the State of California. The authors would like to thank Anna Fryjoff-Hung and Aaron King for GIS mapping assistance, and Kristin Honeycutt and Elena Lopez for important data and technical contributions.

\section{Author Contributions}

Joshua Viers initiated the study. All authors developed conceptual ideas for the analysis and contributed to the discussion. Megan Mayzelle assembled data and carried out the GIS analysis. Thomas Harter contributed hydrogeologic and groundwater related analysis and perspectives and developed the funding for the study, Josue Medellin-Azuara performed the economic analysis. All authors equally contributed to the development, writing, and editing of the manuscript.

\section{Conflicts of Interest}

The authors declare no conflict of interest.

\section{References}

1. Power, A.G. Ecosystem services and agriculture: Tradeoffs and synergies. Philos. Trans. R. Soc. B 2010, 365, 2959-2971.

2. Hoekstra, A.Y.; Chapagain, A.K.; Aldaya, M.M.; Mekonnen, M.M. Water Footprint Assessment Manual: Setting the Global Standard; Earthscan: London, UK, 2011.

3. Foley, J.A. Global consequences of land use. Science 2005, 309, 570-574.

4. Gleick, P. Basic water requirements for human activities: Meeting basic needs. Water Int. 1996, 21, 83-92.

5. Faunt, C.C. Groundwater Availability in the Central Valley Aquifer, California; US Geological Survey Professional Paper 1766; United States Geological Survey (USGS): Reston, VA, USA, 2009.

6. Wada, Y.; van Beek, L.P.H.; van Kempen, C.M.; Reckman, J.W.T.M.; Vasak, S.; Bierkens, M.F.P. Global depletion of groundwater resources. Geophys. Res. Lett. 2010, 37, doi:10.1029/2010GL044571.

7. Galloway, J.N.; Townsend, A.R.; Erisman, J.W.; Bekunda, M.; Cai, Z.; Freney, J.R.; Martinelli, L.A.; Seitzinger, S.P.; Sutton, M.A. Transformation of the nitrogen cycle: Recent trends, questions, and potential solutions. Science 2008, 320, 889-892.

8. Drecht, G.V.; Bouwman, A.F.; Knoop, J.M.; Beusen, A.H.W.; Meinardi, C.R. Global modeling of the fate of nitrogen from point and nonpoint sources in soils, groundwater, and surface water. Glob. Biogeochem. Cycles 2003, 17, 1115-1135.

9. Galloway, J.N.; Dentener, F.J.; Capone, D.G.; Boyer, E.W.; Howarth, R.W.; Seitzinger, S.P.; Asner, G.P.; Cleveland, C.C.; Green, P.A.; Holland, E.A.; et al. Nitrogen cycles: Past, present, and future. Biogeochemistry 2004, 70, 153-226.

10. Natural Resources Conservation Service. Nitrogen Fertilizer Guide Technical Handbook; United States Department of Agriculture: Washington, DC, USA, 2000. 
11. Townsend, A.R.; Howarth, R.W.; Bazzaz, F.A.; Booth, M.S.; Cleveland, C.C. Human health effects of a changing global nitrogen cycle. Front. Ecol. Environ. 2003, 5, 240-246.

12. Nolan, B.T.; Hitt, K.J. Probability of nitrate contamination of recently recharged ground waters. Environ. Sci. Technol. 2011, 36, 2138-2145.

13. Smil, V. Nitrogen in crop production: An account of global flows. Glob. Biogeochem. Cycles 1999, 13, 647-662.

14. McLay, C.D.A.; Dragten, R.; Sparling, G.; Selvarajah, N. Predicting groundwater nitrate concentrations in a region of mixed agricultural land use: A comparison of three approaches. Environ. Pollut. 2001, $115,191-204$.

15. Nolan, B.T. Relating nitrogen sources and aquifer susceptibility to nitrate in shallow ground waters of the United States. Ground Water 2001, 39, 290-299.

16. Lockhart, K.M.; King, A.M.; Harter, T. Identifying sources of groundwater nitrate contamination in a large alluvial groundwater basin with highly diversified intensive agricultural production. J. Contam. Hydrol. 2013, 151, 140-154.

17. Nolan, B.T.; Hitt, K.J. Vulnerability of shallow groundwater and drinking-water wells to nitrate in the United States. Environ. Sci. Technol. 2006, 40, 7834-7840.

18. Schröder, J.J.; Scholefield, D.; Cabral, F.; Hofman, G. The effects of nutrient losses from agriculture on ground and surface water quality: The position of science in developing indicators for regulation. Environ. Sci. Policy 2004, 7, 15-23.

19. Dubrovsky, N.M.; Burow, K.R.; Clark, G.M.; Gronberg, J.M.; Hamilton, P.A.; Hitt, K.J.; Mueller, D.K.; Munn, M.D.; Nolan, B.T.; Puckett, L.J.; et al. Nutrients in the Nation's Streams and Groundwater, 1992-2004; USGS Circular 1350; USGS: Reston, VA, USA, 2010.

20. National Look at Nitrate Contamination of Ground Water; USGS: Reston, VA, USA, 2009.

21. Rabalais, N.N. Nitrogen in aquatic ecosystems. AMBIO 2002, 31, 102-112.

22. Vitousek, P.M.; Aber, J.D.; Howarth, R.W.; Likens, G.E.; Matson, P.A.; Schindler, D.W.; Schlesinger, W.H.; Tilman, D.G. Human alteration of the global nitrogen cycle: Sources and consequences. Ecol. Appl. 1997, 7, 737-750.

23. Wolfe, A.H.; Patz, J.A. Reactive nitrogen and human health: Acute and long-term implications. AMBIO 2002, 31, 120-125.

24. Jackson, R.B.; Carpenter, S.R.; Dahm, C.N.; McKnight, D.M.; Naiman, R.J.; Postel, S.L.; Running, S.W. Water in a changing world. Ecol. Appl. 2001, 11, 1027-1045.

25. Oki, T.; Kanae, S. Global hydrological cycles and world water resources. Science 2006, 313, 1068-1072.

26. Nitrate and Nitrite Human Health Fact Sheet; Argonne National Laboratory: DuPage County, IL, USA, 2005.

27. Nitrates/Nitrites Chemical Fact Sheet; World Health Organization: Geneva, Switzerland, 2003.

28. United States Environmental Protection Agency. Basic Information about Nitrate in Drinking Water. Available online: http://water.epa.gov/drink/contaminants/basicinformation/nitrate.cfm (accessed on 13 July 2011). 
29. Jensen, V.B.; Darby, J.L.; Seidel, C.; Gorman, C. Technical Report 6 of Addressing Nitrate in California's Drinking Water with a Focus on Tulare Lake Basin and Salinas Valley Groundwater Report for the State Water Resources Control Board Report to the Legislature: Drinking Water Treatment for Nitrate; University of California, Davis, Center for Watershed Science: Davis, CA, USA, 2012.

30. Harter, T.; Lund, J.; Darby, J.; Fogg, G.; Howitt, R.; Jessoe, K.; Pettygrove, S.; Quinn, J.; Viers, J. Addressing Nitrate in California's Drinking Water with a Focus on Tulare Lake Basin and Salinas Valley Groundwater Report for the State Water Resources Control Board Report to the Legislature; University of California, Davis, Center for Watershed Science: Davis, CA, USA, 2012.

31. Hanley, N. The economics of nitrate pollution. Eur. Rev. Agric. Econ. 1990, 17, 129-151.

32. Döll, P.; Fiedler, K. Global-scale modeling of groundwater recharge. Hydrol. Earth Syst. Sci. 2008, $12,863-885$.

33. Frind, E.O.; Molson, J.W.; Rudolph, D.L. Well vulnerability: A quantitative approach for source water protection. Groundwater 2006, 44, 732-742.

34. Rudolph, D. Quantifying the Performance of Regional Scale Reductions in Nutrient Applications for Source Water Protection through Vadose Zone Monitoring; Toward Sustainable Groundwater in Agriculture: San Francisco, CA, USA, 2010.

35. Boyle, D.; King, A.; Kourakos, G.; Lockhart, K.; Mayzelle, M.; Fogg, G.E.; Harter, T. Technical Report 4 of Addressing Nitrate in California's Drinking Water with a Focus on Tulare Lake Basin and Salinas Valley Groundwater Report for the State Water Resources Control Board Report to the Legislature; Groundwater Nitrate Occurrence; University of California, Davis, Center for Watershed Science: Davis, CA, USA, 2012.

36. Almasri, M.N.; Kaluarachchi, J.J. Assessment and management of long-term nitrate pollution of ground water in agriculture-dominated watersheds. J. Hydrol. 2004, 295, 225-245.

37. California Agricultural Statistics; United States Department of Agriculture National Agricultural Statistics Service (USDA NASS): Washington, DC, USA, 2010.

38. United States Department of Agriculture Economic Research Sevice (USDA ERS), California Fact Sheet, 2010. Available online: http://www.ers.usda.gov/StateFacts/CA.htm (accessed on 20 July 2011).

39. Tadlock, C. California's San Joaquin Valley: A Region of Transition; Congressional Research Service: Washington, DC, USA, 2005.

40. Water \& Health in the Valley: Nitrate Contamination of Drinking Water and the Health of San Joaquin Valley Residents; Health and Drinking Water Series; Community Water Center: Visalia, CA, USA, 2011.

41. Bianchi, M.; Harter, T. Nonpoint Sources of Pollution in Irrigated Agriculture; ANR Publication 8055; University of California, Davis: Davis, CA, USA, 2002.

42. Dubrovsky, N.M.; Kratzer, C.R.; Brown, L.R.; Gronberg, J.M.; Burow, K.R. Water Quality in the San Joaquin-Tulare Basins, California, 1992-95; Circular 1159; USGS: Washington, DC, USA, 1998.

43. Groundwater Ambient Monitoring and Assessment (GAMA): Domestic Well Project Groundwater Quality Data Report Tulare County Focus Area; California State Water Resources Control Board Groundwater Protection Section: Sacramento, CA, USA, 2010. 
44. Moore, E.; Matalon, E.; Balazs, C.; Clary, J. The Human Costs of Nitrate-contaminated Drinking Water in the San Joaquin Valley; Pacific Institute: Oakland, CA, USA, 2011.

45. Balazs, C.; Morello-Frosch, R.; Hubbard, A.; Ray, I. Social disparities in nitrate contaminated drinking water in California's San Joaquin Valley. Environ. Health Perspect. 2011, 119, 1272-1278.

46. Reed, D. California Counts: Population Trends and Profiles; Public Policy Institute of California: San Francisco, CA, USA, 2006; Volume 7.

47. Cantatore, A. United Nations Takes Issue with Water Quality in Central Valley. Available online: http: //www.turlockjournal.com/section/12/article/11293/ (accessed on 20 September 2011).

48. UN News Centre. Rich Countries Fall Short on Providing Safe Water, Sanitation for All-UN Expert. Available online: http: //www.un.org/apps/news/story.asp?NewsID=39590\&Cr=sanitation $\& \mathrm{Cr} 1=\mathrm{http}: / /$ www.un.org/apps/news/story.asp?NewsID $=39590 \& \mathrm{Cr}=$ sanitation $\& \mathrm{Cr} 1=$ (accessed on 20 September 2011).

49. Harter, T.; Rollins, L. Watersheds, Groundwater and Drinking Water: A Practical Guide; Publication 3497 Vols; University of California Agriculture and Natural Resources: Davis, CA, USA, 2008.

50. California Department of Public Health. Drinking Water Source Assessment and Protection Program, Drinking Water Source Assessment and Protection Program, 2007. Available online: http://www.cdph.ca.gov/certlic/drinkingwater/pages/dwsap.aspx (accessed on 6 October 2013).

51. Cooley, H.; Christian-Smith, J.; Gleick, P.H.; Cohen, M.; Allen, L. Understanding and Reducing the Risks of Climate Change for Transboundary Waters; Pacific Institute: Oakland, CA, USA, 2009.

52. Public Policy Institute of California, Per Capita Urban Water Use: 1960-2005, 2012. Available online: http: //www.ppic.org/main/mapdetail.asp?pp=988 (accessed on 11 October 2012).

53. Kunstmann, H.; Kastens, M. Determination of stochastic well head protection zones by direct propagation of uncertainties of particle tracks. J. Hydrol. 2006, 323, 215-229.

54. Posen, P.; Hutchins, M.; Lovett, A.; Davies, H. Identifying the catchment size at which robust estimations of agricultural land use can be made, and implications for diffuse pollution modelling. Appl. Geogr. 2011, 31, 919-929.

55. Bremer, J.; Harter, T. Domestic wells have high probability of pumping septic tank leachate. Hydrol. Earth Syst. Sci. 2012, 16, 2453-2467.

56. Esling, S.P.; Keller, J.E.; Miller, K.J. Reducing capture zone uncertainty with a systematic sensitivity analysis. Groundwater 2008, 46, 570-578.

57. Johnson, S.L.; Adams, R.M.; Perry, G.M. The on-farm costs of reducing groundwater pollution. Am. J. Agric. Econ. 1991, 73, 1063-1073.

58. Rosenstock, T.S.; Liptzin, D.; Dzurella, K.N.; Fryjoff-Hung, A.; Hollander, A.; Jensen, V.; King, A.; Kourakos, G.; McNally, A.; Pettygrove, S.; et al. Agriculture's contribution to nitrate contamination of Californian groundwater (1945 to 2005). J. Environ. Q. 2013, 43, 895-907.

59. Viers, J.H.; Liptzin, D.; Rosenstock, T.S.; Jensen, V.B.; Hollander, A.D.; McNally, A.; King, A.M.; Kourakos, G.; Lopez, E.M.; de La Mora, N.; et al. Technical Report 2 of Addressing Nitrate in California's Drinking Water with a Focus on Tulare Lake Basin and Salinas Valley Groundwater Report for the State Water Resources Control Board Report to the Legislature: Nitrogen Sources and Loading to Ground Water; University of California, Davis, Center for Watershed Science: Davis, CA, USA, 2012. 
60. Burow, K.R.; Shelton, J.L.; Dubrovsky, N.M. Occurrence of Nitrate and Pesticides in Groundwater Beneath Three Agricultural Land-Use Settings in the Eastern San Joaquin Valley, California, 1993-1995; Water Resources Investigation Report 97-4284; USGS: Reston, VA, USA, 1998.

61. Rosenstock, T.S.; Liptzin, D.; Six, J.; Tomich, T.P. Nitrogen fertilizer use in California: Assessing the data, trends and a way forward. Calif. Agric. 2013, 67, 68-79.

62. Letey, J.; Blair, J.W.; Devitt, D.; Lund, L.J.; Nash, P. Final Report to the National Science Foundation for Grant Nos. GI34733X, GI43664, AEN74-11136 A01, ENV76-10283 and PFR76-10283 Nitrate in Effluents from Irrigated Lands; University of California: Berkeley, CA, USA, 1979.

63. Nolan, B.T.; Hitt, K.J.; Ruddy, B.C. Probability of nitrate contamination of recently recharged groundwaters in the conterminous United States. Environ. Sci. Policy 2002, 36, 2138-2145.

64. Delgado, J.A.; Shaffer, M.; Hu, C.; Lavado, R.S.; Wong, J.C.; Joosse, P.; Li, X.; Rimski-Korsakov, H.; Follett, R.; Colon, W.; et al. A decade of change in nutrient management: A new nitrogen index. J. Soil Water Conserv. 2006, 61, 62A-71A.

65. Wu, L.; Letey, J.; French, C.; Wood, Y.; Birkle, D. Nitrate leaching hazard index developed for irrigated agriculture. J. Soil Water Conserv. 2005, 60, 90A-95A.

66. Reeves, D.W. The role of soil organic matter in matintaining soil quality in continuous cropping systems. Soil Tillage Res. 1997, 43, 131-167.

67. Bachand, P.A.M.; Horwath, W.R.; Roy, S.B.; Choperena, J.; Cameron, D. Implications of Using On-Farm Flood Flow Capture to Recharge Groundwater and Mitigate Flood Risks Along the Kings River, CA; United States Department of Agriculture, Natural Resources Conservation Service, Bachand and Associates: Washington, DC, USA, 2012.

68. Water Resources \& Information and Management Engineering, Inc. Kings Basin Integrated Groundwater and Surface Water Model (IGSM) Model Development and Calibration; Upper Kings Basin Water Forum Kings River Conservation District and City of Fresno: Fresno, CA, USA, 2007.

69. Kadlec, R.H.; Sujoy, B.R.; Munson, R.K.; Charlton, S.; Brownlie, W. Water quality performance of treatment wetlands in the Impreial Valley, California. Ecol. Eng. 2010, 36, 1093-1107.

70. Kalcic, M.; Chaubey, I.; Frankenberger, J.; Kladivko, E. A geospatial approach to targeting constructed wetlands for nitrate removal in agricultural watersheds. Appl. Eng. Agric. 2012, 28, 347-357.

71. US Census Bureau, State and County Quick Facts. 2011. Available online http://quickfacts.census.gov/qfd/states/06/06019.html (accessed on 21 September 2011).

72. Census Designated Place (CDP) Program for the 2010 Census-Final Criteria; Federal Registered Document E8-2667; United States Census Bureau: Suitland, MD, USA, 2008.

73. State of California. CAL. PRC. CODE § 4799.09: California Code-Section 4799.09. Available online: http://codes.lp.findlaw.com/cacode/PRC/1/d4/2.5/2/s4799.09 (accessed on 15 July 2011).

74. Hollander, A.D. California Augmented Multisource Landcover Map; Information Center for the Environment, Technical Report; University of California, Davis: Davis, CA, USA, 2010.

75. California State Water Resources Control Board. Groundwater Ambient Monitoring and Assessment Program. California Environmental Protection Agency 2013. Available online: http: //www.waterboards.ca.gov/gama/geotracker_gama.shtml (accessed on 13 July 2011). 
76. Revised Monitoring and Reporting Program Order No. R5-2007-0035 General Order for Existing Milk Cow Dairies; California Regional Water Quality Control Board Central Valley Region: Sacramento, CA, USA, 2007.

77. Howitt, R.; Medellin-Azuara, J.; MacEwan, D.; Lund, J. The California Statewide Agricultural Production Model. UC Davis, 2012. Available online: http://swap.ucdavis.edu/ (accessed on 1 July 2013).

78. Environmental Systems Research Institute (ESRI). ArcGIS v. 10. Available online: http://www.esri.com/software/arcgis/new (accessed on 1 July 2013).

79. Day, F. Principles of Impact Analysis and IMPLAN Applications; Minnesota IMPLAN group: Minneapolis, MN, USA, 2010.

80. Minnesota IMPLAN group. Corp. IMPLAN, 2012. Available Online: http://implan.com/V4/ Index.php (accessed on 21 July 2013).

81. NAICS Sector 11-Agriculture, Forestry, Fishing, and Hunting; United States Census Bureau: Suitland, MD, USA, 2007.

82. California Agricultural Resource Directory; United States Department of Agriculture. National Agricultural Statistics Service California Field Office: Reston, VA, USA, 2009.

83. Frate, C.; Mueller, S.; Campbell-Mathews, M.; Canevari, M.; Klonsky, K.; de Moura, R. Sample Costs to Establish and Produce Alfalfa; University of California Cooperative Extension: Davis, CA, USA, 2008.

84. Verdegaal, P.; Klonsky, K.; de Moura, R. Sample Costs to Establish a Vineyard and Produce Winegrapes; University of California Cooperative Extension: Davis, CA, USA, 2012.

85. Narayanan, A.; Pitt, R. Costs of Urban Stormwater Control Practices; Department of Civil Construction and Environmental Engineering, University of Alabama: Tuscaloosa, AL, USA, 2006.

86. Bachand, P.A.M.; Horwath, W.R.; Roy, S.B.; Choperena, J.; Cameron, D. On-Farm Flood Flow Capture-Addressing Flood Risks and Groundwater Overdraft in the Kings Basin; Natural Resources Conservation District and Kings River Conservation District: Fresno, CA, USA, 2011.

87. California Department of Water Resources. Central Valley Flood Protection Program, 2012. Available online: http://www.water.ca.gov/cvfmp/ (accessed on 1 July 2013).

88. Kourakos, G.; Klein, F.; Cortis, A.; Harter, T. A groundwater nonpoint source pollution modeling framework to evaluate long-term dynamics of pollutant exceedance probabilities in wells and other discharge locations. Water Resourc. Res. 2012, 48, doi:10.1029/2011WR010813.

(C) 2014 by the authors; licensee MDPI, Basel, Switzerland. This article is an open access article distributed under the terms and conditions of the Creative Commons Attribution license (http://creativecommons.org/licenses/by/4.0/). 